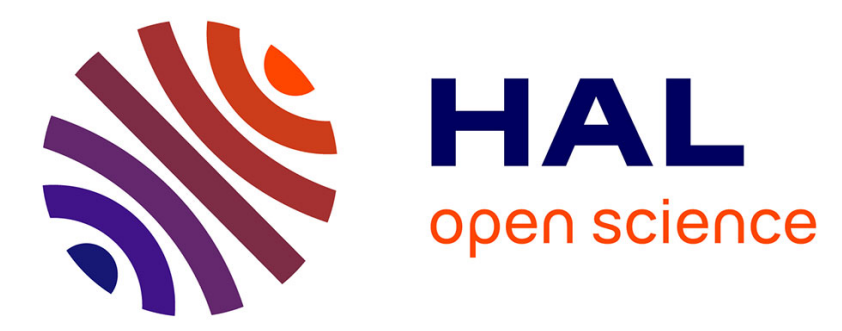

\title{
The crystal structure of $\mathrm{Bi} 2 \mathrm{~W} 6 \mathrm{Br} 18$ and a new synthesis of $\mathrm{W} 6 \mathrm{Br} 12$ \\ Hans-Juergen Meyer
}

\section{To cite this version:}

Hans-Juergen Meyer. The crystal structure of Bi2W6Br18 and a new synthesis of W6Br12. Journal of Inorganic and General Chemistry / Zeitschrift für anorganische und allgemeine Chemie, 2010, 636 (9-10), pp.1817. 10.1002/zaac.201000071 . hal-00599857

\section{HAL Id: hal-00599857 https://hal.science/hal-00599857}

Submitted on 11 Jun 2011

HAL is a multi-disciplinary open access archive for the deposit and dissemination of scientific research documents, whether they are published or not. The documents may come from teaching and research institutions in France or abroad, or from public or private research centers.
L'archive ouverte pluridisciplinaire HAL, est destinée au dépôt et à la diffusion de documents scientifiques de niveau recherche, publiés ou non, émanant des établissements d'enseignement et de recherche français ou étrangers, des laboratoires publics ou privés. 


\section{The crystal structure of Bi2W6Br18 and a new synthesis of W6Br12}

\begin{tabular}{|c|c|}
\hline Journal: & Zeitschrift für Anorganische und Allgemeine Chemie \\
\hline Manuscript ID: & zaac. $201000071 . R 1$ \\
\hline Wiley - Manuscript type: & Article \\
\hline $\begin{array}{r}\text { Date Submitted by the } \\
\text { Author: }\end{array}$ & 07-Mar-2010 \\
\hline Complete List of Authors: & Meyer, Hans-Juergen \\
\hline Keywords: & tungsten cluster, bromide, synthesis \\
\hline
\end{tabular}

\section{scholaroNE" \\ Manuscript Central}




\section{Figure Captions}

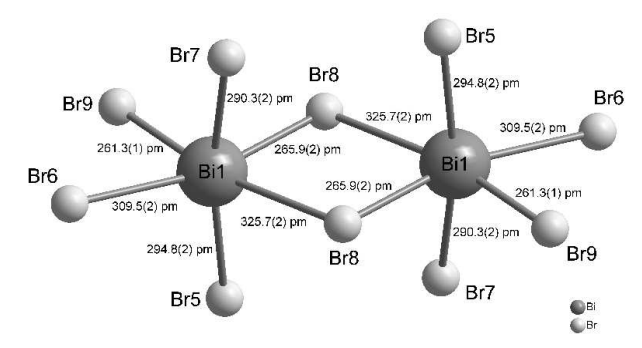

Figure 1. Projection of the environment of pairs of bismuth atoms in the structure containing two short $\mathrm{Bi}-\mathrm{Br}$ distances each.

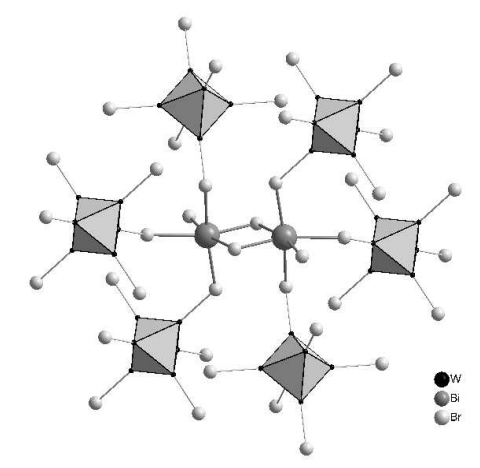

Figure 2. Connectivity of $\left(\mathrm{BiBr}_{2}\right)_{2}$ units with outer bromide cluster ligands. $\left(\mathrm{W}_{6} \mathrm{Br}_{8}{ }^{\mathrm{i}}\right)$ clusters are shown as octahedra.

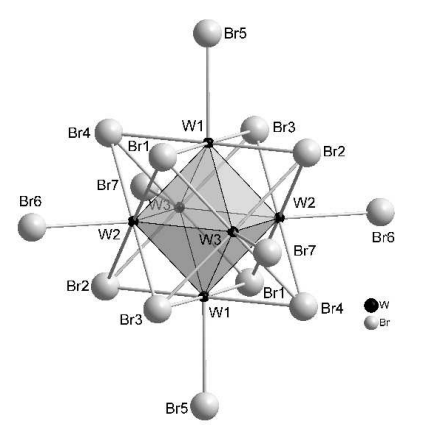

Figure 3. Projection of an isolated $\left[\left(\mathrm{W}_{6} \mathrm{Br}_{8}{ }^{i}\right) \mathrm{Br}_{6}{ }^{a}\right]^{2-}$ cluster.

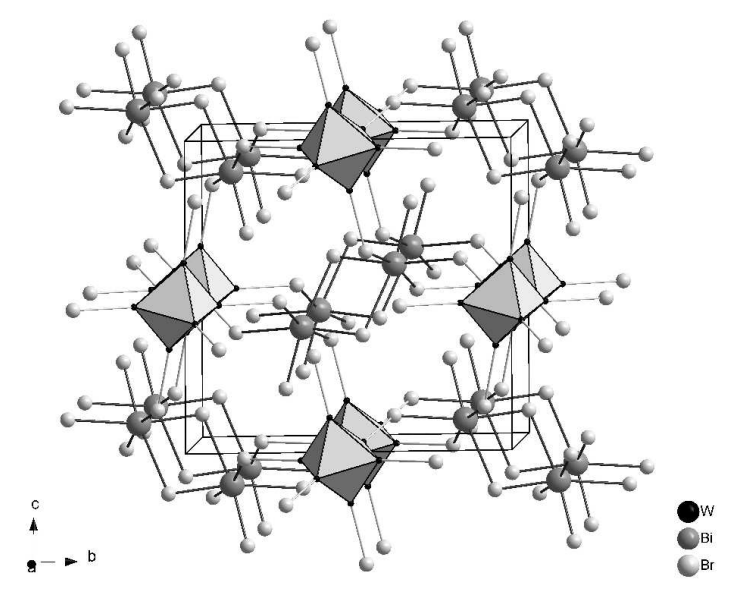

Figure 4. Unit cell of $\left(\mathrm{BiBr}_{2}\right)_{2}\left[\left(\mathrm{~W}_{6} \mathrm{Br}_{8}{ }^{i}\right) \mathrm{Br}_{6}{ }^{a}\right]$ (inner $\mathrm{Br}$ ligands are omitted). 


\title{
The crystal structure of $\mathrm{Bi}_{2} \mathrm{~W}_{6} \mathrm{Br}_{18}$ and a new synthesis of $\mathrm{W}_{6} \mathrm{Br}_{12}$
}

\author{
Markus Ströbele ${ }^{[a]}$ and H.-Jürgen Meyer*[a] \\ Dedicated to Professor Bernd Harbrecht on the Occasion of his 60th Birthday
}

Keywords: Tungsten cluster; Bromide; Synthesis; Structure

\begin{abstract}
The new tungsten bromide cluster compound $\mathrm{Bi}_{2} \mathrm{~W}_{6} \mathrm{Br}_{18}$ was synthesized by reacting tungsten hexabromide with bismuth metal in a silica tube at $350{ }^{\circ} \mathrm{C}$. The structure of $\mathrm{Bi}_{2} \mathrm{~W}_{6} \mathrm{Br}_{18}$ was refined by single crystal $\mathrm{X}$-ray diffraction in the space group $P 2_{1} / c$ with unit cell dimensions of $a=981.8(2) \mathrm{pm}, b=1305.9(2) \mathrm{pm}, c=1256.8(2) \mathrm{pm}$ and $\beta=101.81(2)^{\circ}$.

The crystal structure is constructed from $\left[\left(\mathrm{W}_{6} \mathrm{Br}_{8}{ }^{\mathrm{i}}\right) \mathrm{Br}_{6}{ }^{\mathrm{a}}\right]^{2-}$ anions being interconnected by outer bromine ligands with $\left(\mathrm{BiBr}_{2}\right)$ units, which behave as cations in $\left(\mathrm{BiBr}_{2}\right)_{2}\left[\left(\mathrm{~W}_{6} \mathrm{Br}_{8}\right) \mathrm{Br}_{6}\right]$. Short $\mathrm{Bi}-$ $\mathrm{Br}$ bonding distances at 261.3(1) pm and 265.9(2) pm in $\left(\mathrm{BiBr}_{2}\right)$ units suggest the presence of covalent interactions. Thermal decomposition of the compound leads to $\mathrm{W}_{6} \mathrm{Br}_{12}$.
\end{abstract}

\author{
* Prof. Dr. H.-Jürgen Meyer \\ E-mail: juergen.meyer@uni-tuebingen.de \\ [a] Abteilung für Festkörperchemie und Theoretische Anorganische Chemie \\ Institut für Anorganische Chemie \\ Ob dem Himmelreich 7 \\ Universität Tübingen \\ D-72074 Tübingen
}




\section{Introduction}

Tungsten halide cluster chemistry is represented by a remarkable widespread domain of different compounds and structures. Currently known tungsten clusters are represented by the octahedral $\left[\mathrm{W}_{6} \mathrm{X}_{12}\right]$ type cluster of $\mathrm{W}_{6} \mathrm{Cl}_{18}[1,2]$, the octahedral $\left[\mathrm{W}_{6} \mathrm{X}_{8}\right]$ type cluster of $\mathrm{W}_{6} \mathrm{X}_{12}$ with $\mathrm{X}=\mathrm{Cl}, \mathrm{Br}$ [3], and the centered trigonal prismatic cluster core in $\mathrm{W}_{6} \mathrm{CCl}_{18}$ [4]. Mixtures of such clusters were obtained in the structure of $\mathrm{W}_{30} \mathrm{C}_{2} \mathrm{X}_{68}(\mathrm{X}=\mathrm{Cl}, \mathrm{Br})$ containing carbon centered trigonal prismatic and octahedral cluster moieties in one structure [5]. More cluster types have been discovered in the field of tungsten iodides [6], just recently extended by the identification of the binary compound $\mathrm{W}_{15} \mathrm{I}_{47}$ containing a square pyramidal cluster core [7].

Based on these tungsten halide clusters, several salt-like compounds have been synthesized in which clusters act as bulky anions [8]. Compounds with $\left[\mathrm{W}_{6} \mathrm{X}_{8}\right]$ type clusters have been reported with monovalent $A$ ions in $\mathrm{AW}_{6} \mathrm{Cl}_{13}, \mathrm{~A}_{2} \mathrm{~W}_{6} \mathrm{Cl}_{14}[9,10,11]$, and with trivalent $\mathrm{M}$ ions in $\mathrm{MW}_{6} \mathrm{Cl}_{15} \mathrm{M}=\mathrm{Bi}[12,13], \mathrm{Gd}, \mathrm{Tb}$, Dy [14]. Corresponding cluster bromides were reported as $\mathrm{NaW}_{6} \mathrm{Br}_{13}$ [15], $A \mathrm{~W}_{6} \mathrm{Br}_{14}$ with $\mathrm{A}=\mathrm{Na}, \mathrm{Ag}$ [16], and $\mathrm{A}_{2} \mathrm{~W}_{6} \mathrm{Br}_{14}$ with $\mathrm{A}=\mathrm{Ag}$ [16], $\mathrm{K}$ [17], $\mathrm{Rb}$ [17], Cs [18], TI [17], Cd [19], and Cu [20].

The synthesis of $\mathrm{W}_{6} \mathrm{Cl}_{12}$ has been recently established by a convenient low-temperature route based on the reduction of $\mathrm{WCl}_{6}$ with bismuth metal at $335{ }^{\circ} \mathrm{C}$ [21]. The structural characterization of the intermediate $\mathrm{BiW}_{6} \mathrm{Cl}_{15}$ revealed a constitutional isomerism of this compound, which may be described by the two formulas $(\mathrm{BiCl})\left[\left(\mathrm{W}_{6} \mathrm{Cl}_{8}{ }^{i}\right) \mathrm{Cl}_{6}{ }^{a}\right]$ [12] and $\left(\mathrm{BiCl}_{2}\right)\left[\left(\mathrm{W}_{6} \mathrm{Cl}_{8}{ }^{\mathrm{i}}\right) \mathrm{Cl}_{4}{ }^{\mathrm{a}} \mathrm{Cl}_{2 / 2}{ }^{\mathrm{a}-\mathrm{a}}\right]$ [13]. The main differences in these structures are expressed by short $\mathrm{Bi}-\mathrm{Cl}$ distances at $249 \mathrm{pm}$ for $(\mathrm{BiCl})^{2+}$ and at $245 \mathrm{pm}$ for $\left(\mathrm{BiCl}_{2}\right)^{+}$with chloride ligands which remain unconnected with respect to the tungsten cluster. The similarity with the previously reported isotypic structure of $(\mathrm{BiCl})\left[\mathrm{Mo}_{6} \mathrm{Cl}_{8}{ }_{8}{ }^{i} \mathrm{Cl}_{6}{ }^{a}\right.$ [22] suggests a close relationship in chemistry of these compounds.

The present work proves the reactivity of tungsten hexabromide with metallic bismuth in order to develop a useful and comfortable synthesis of $\mathrm{W}_{6} \mathrm{Br}_{12}$ as an alternative route to the reported reaction between tungsten metal and bromine. In course of this study, namely through reaction of $\mathrm{WBr}_{6}$ and metallic bismuth, we discovered the new compound $\mathrm{Bi}_{2} \mathrm{~W}_{6} \mathrm{Br}_{18}$, whose crystal structure is reported herein.

\section{Experimental Section}

\section{Synthesis of $\mathrm{Bi}_{2} \mathrm{~W}_{6} \mathrm{Br}_{18}$}

Manipulations of the starting materials $\mathrm{WBr}_{6}$ and $\mathrm{Bi}$ (Riedel-de Haen, $99 \%$ ) were performed in a dry box under argon atmosphere. A mixture of $\operatorname{WBr}_{6}(0.5 \mathrm{~g}, 0.75 \mathrm{mmol})$ and elementary $\mathrm{Bi}(0.21 \mathrm{~g}, 1 \mathrm{mmol})$ were charged into a two chamber silica tube and sealed under vacuum. This mixture was heated in a tube furnace at $350{ }^{\circ} \mathrm{C}$ for $48 \mathrm{~h}$. Afterwards, the coproduced 
$\mathrm{BiBr}_{3}$ was sublimed off from the bulk part (later identified as $\mathrm{Bi}_{2} \mathrm{~W}_{6} \mathrm{Br}_{18}$ ) into the receiver chamber of the silica vessel, being exposed with a lower temperature (near room temperature) over the period of two days. Finally, the ampoule was cooled down to room temperature, the receiver chamber was disconnected from the product chamber, and the content of the product chamber was collected inside the dry box. Dark amber colored rhombic crystals of the new $\mathrm{Bi}_{2} \mathrm{~W}_{6} \mathrm{Br}_{18}$ were selected for $\mathrm{X}$-ray single crystal structure analysis.

When the mixture was treated at slightly higher temperatures (at $370{ }^{\circ} \mathrm{C}$ for one week) $\mathrm{Bi}_{2} \mathrm{~W}_{6} \mathrm{Br}_{18}$ was decomposed into $\mathrm{W}_{6} \mathrm{Br}_{12}$ and coproduced $\mathrm{BiBr}_{3}$, which was subsequently sublimed off.

\section{Synthesis of $\left(\mathrm{H}_{3} \mathrm{O}\right)_{2}\left[\mathrm{~W}_{6} \mathrm{Br}_{14}\right] \cdot 4 \mathrm{H}_{2} \mathrm{O}$}

$\mathrm{Bi}_{2} \mathrm{~W}_{6} \mathrm{Br}_{18}$ was dissolved in boiling concentrated $\mathrm{HBr}$ solution. Brownish crystals of $\left(\mathrm{H}_{3} \mathrm{O}\right)_{2}\left[\mathrm{~W}_{6} \mathrm{Br}_{14}\right] \cdot 4 \mathrm{H}_{2} \mathrm{O}$ were crystallized upon cooling the solution to room temperature.

\section{Synthesis of $\mathrm{WBr}_{6}$}

A Schlenk tube with two gas cocks was charged with $3 \mathrm{~g}(8.5 \mathrm{mmol}) \mathrm{W}(\mathrm{CO})_{6}(\mathrm{ABCR}, 99 \%)$ in a dry box under argon atmosphere. Afterwards, the tube inlet was connected to an argon line in order to provide an inert gas atmosphere, and the outlet was equipped with three empty washing bottles. After the vessel was cooled with liquid nitrogen, $12.8 \mathrm{ml}$ of liquid $\mathrm{Br}_{2}$ $(0.5 \mathrm{~mol})$ were added to the solid $\mathrm{W}(\mathrm{CO})_{6}$. The reaction was initiated by allowing the vessel to warm up slowly to room temperature by removing the liquid nitrogen coolant. After resting for $30 \mathrm{~min}$. at room temperature the three washing bottles were filled with alkaline sodium sulfite solution and the Schlenk tube was heated in a water bath to remove the excess of bromine from the reaction. The residual dark gray $\mathrm{WBr}_{6}$ powder was collected inside the dry box.

\section{$X$-ray Diffraction}

The XRD patterns of reaction products were collected with a Stadi-P (Stoe, Darmstadt) powder diffractometer using $\mathrm{Cu}-\mathrm{K}_{\alpha 1}$ radiation (germanium monochromator), with $\mathrm{Bi}_{2} \mathrm{~W}_{6} \mathrm{Br}_{18}$ and $\left(\mathrm{H}_{3} \mathrm{O}\right)_{2}\left[\mathrm{~W}_{6} \mathrm{Br}_{14}\right] \cdot 4 \mathrm{H}_{2} \mathrm{O}$ being obtained X-ray pure, although $\mathrm{WBr}_{6}$ contained some small amounts of $\mathrm{WOBr}_{4}$ (about $5 \%$ ) which may be a result of an oxygen contamination of $\mathrm{W}(\mathrm{CO})_{6}$. A single crystal of $\mathrm{Bi}_{2} \mathrm{~W}_{6} \mathrm{Br}_{18}$ was coated with lithelen grease and attached to the tip of a glass fibre. Single crystal diffraction data were collected with an IPDS diffractometer (STOE, Darmstadt) using monochromated $\mathrm{Mo} \mathrm{K}_{\alpha}$ radiation. The unit cell refinement and data reduction were carried out using the STOE IPDS software. An absorption correction was applied by using the programs X-Shape/X-Red [23]. The structure was refined in the space 


\section{Results and Discussion}

The compound $\mathrm{Bi}_{2} \mathrm{~W}_{6} \mathrm{Br}_{18}$ was prepared by metallothermic reduction of $\mathrm{WBr}_{6}$ with bismuth metal at $350{ }^{\circ} \mathrm{C}$. However, $\mathrm{Bi}_{2} \mathrm{~W}_{6} \mathrm{Br}_{18}$ is thermally labile and decomposes slowly at temperatures above $370{ }^{\circ} \mathrm{C}$ to yield $\mathrm{W}_{6} \mathrm{Br}_{12}$ and $\mathrm{BiBr}_{3}$, of which the latter can be sublimed off into the colder section (room temperature) of the reaction vessel. This procedure, as emphasized in the following reaction equations permits a comfortable access to obtain pure $\mathrm{W}_{6} \mathrm{Br}_{12}$.

$$
\begin{aligned}
& 6 \mathrm{WBr}_{6}+8 \mathrm{Bi} \rightarrow \mathrm{Bi}_{2} \mathrm{~W}_{6} \mathrm{Br}_{18}+6 \mathrm{BiBr}_{3} \\
& \mathrm{Bi}_{2} \mathrm{~W}_{6} \mathrm{Br}_{18} \rightarrow \mathrm{W}_{6} \mathrm{Br}_{12}+2 \mathrm{BiBr}_{3}
\end{aligned}
$$

The composition $\mathrm{Bi}_{2} \mathrm{~W}_{6} \mathrm{Br}_{18}$ may suggest a relationship with $\mathrm{A}_{2}\left[\mathrm{~W}_{6} \mathrm{Cl}_{18}\right]$ compounds containing $\left[\left(\mathrm{W}_{6} \mathrm{Cl}_{12}{ }^{\mathrm{i}}\right) \mathrm{Cl}_{6}{ }^{\mathrm{a}}\right]^{2-}$ ions [8]. However, the crystal structure of $\mathrm{Bi}_{2} \mathrm{~W}_{6} \mathrm{Cl}_{18}$ was refined to yield a structure which can be described as $\left(\mathrm{BiBr}_{2}\right)_{2}\left[\left(\mathrm{~W}_{6} \mathrm{Br}_{8}{ }^{i}\right) \mathrm{Br}_{6}{ }^{a}\right]$, reflecting a structural relation to the already known bismuth chloro-tungstenate $(\mathrm{BiCl})\left[\left(\mathrm{W}_{6} \mathrm{Cl}_{8}{ }^{i}\right) \mathrm{Cl}_{6}{ }^{a}\right]$. The structure of $\left(\mathrm{BiBr}_{2}\right)_{2}\left[\left(\mathrm{~W}_{6} \mathrm{Br}_{8}{ }^{i}\right) \mathrm{Br}_{6}{ }^{a}\right]$ contains two bromine atoms being involved in covalent bonding with bismuth, thus allowing a $\left(\mathrm{BiBr}_{2}\right)$ moiety to act as a monovalent cation like $\mathrm{A}^{(+)}$in $\mathrm{A}_{2}\left[\left(\mathrm{~W}_{6} \mathrm{Br}_{8}{ }^{\mathrm{i}}\right) \mathrm{Br}_{6}{ }^{\mathrm{a}}\right]$ compounds.

The two short $\mathrm{Bi}-\mathrm{Br}$ distances with $\operatorname{Br}(8)$ at 265.9(2) pm and $\operatorname{Br}(9)$ at 261.3(1) pm are contained in a strongly distorted edge-sharing bi-octahedral $\mathrm{Bi}_{2} \mathrm{Br}_{10}$ moiety, displayed in Figure 1. All the remaining bromide atoms of this moiety, with $\mathrm{Bi}-\mathrm{Br}$ distances presented in Table 3 can be referred as outer ligands of the tungsten cluster (Figure 2).

The $\left[\left(\mathrm{W}_{6} \mathrm{Br}_{12}{ }^{\mathrm{i}}\right) \mathrm{Br}_{6}{ }^{\mathrm{a}}\right]^{2-}$ cluster (Figure 3 ) in the structure exhibits $\mathrm{W}-\mathrm{W}$ distances ranging from 261.94(7) to $264.13(7) \mathrm{pm}, \mathrm{W}-\mathrm{Br}^{\mathrm{i}}$ distances ranging from 260.1(2) to 262.8(1) pm, and $\mathrm{W}-$ $\mathrm{Br}^{\mathrm{a}}$ distances ranging from 257.4(2) to 264.2(2) pm. All these distances reflect typical values among bromo-tungstenate cluster units of this type.

The crystal structure of $\left(\mathrm{BiBr}_{2}\right)_{2}\left[\left(\mathrm{~W}_{6} \mathrm{Br}_{8}{ }^{i}\right) \mathrm{Br}_{6}{ }^{a}\right]$ is displayed in Figure 4 and shows a CsCl type 
like structural arrangement of bi-octahedral $\left(\mathrm{Bi}_{2} \mathrm{Br}_{10}\right)$ units and $\left(\mathrm{W}_{6} \mathrm{Br}_{8}\right)$ cluster units. Six out of ten bromides of the bi-octahedral $\left(\mathrm{Bi}_{2} \mathrm{Br}_{10}\right)$ unit are in fact outer bromide ligands of the cluster (Figure 2).

The given, straight forward synthesis of $\mathrm{W}_{6} \mathrm{Br}_{12}$ would be challenging for the preparation of the corresponding tungsten dichloride, $\mathrm{W}_{6} \mathrm{Cl}_{12}$, too. The related bismuth chloro-tungstenate precursor having the formula $\mathrm{BiW}_{6} \mathrm{Cl}_{15}$ has shown to behave thermally stable up to $340{ }^{\circ} \mathrm{C}$. Thermal treatments at higher temperatures appeared inadequate for $\mathrm{BiW}_{6} \mathrm{Cl}_{15}$ because $\mathrm{W}_{6} \mathrm{Cl}_{12}$ has shown to react with quartz tubing above $350{ }^{\circ} \mathrm{C}$. Therefore, a purification process via solution has been used subsequently for the synthesis of $\mathrm{W}_{6} \mathrm{Cl}_{12}$ [21]. Following this procedure, both, the chloride and bromide compounds can be dissolved into their aqueous $\mathrm{HCl}$ and $\mathrm{HBr}$ solutions to yield $\left(\mathrm{H}_{3} \mathrm{O}\right)_{2}\left[\mathrm{~W}_{6} \mathrm{Cl}_{14}\right] \cdot 7 \mathrm{H}_{2} \mathrm{O}$ and $\left(\mathrm{H}_{3} \mathrm{O}\right)_{2}\left[\mathrm{~W}_{6} \mathrm{Br}_{14}\right] \cdot 4 \mathrm{H}_{2} \mathrm{O}$, respectively. A structure refinement based on a single crystal measurement of $\left(\mathrm{H}_{3} \mathrm{O}\right)_{2}\left[\mathrm{~W}_{6} \mathrm{Br}_{14}\right] \cdot 4 \mathrm{H}_{2} \mathrm{O}$ (with crystal data being deposited in the ICSD) has shown that the structures of both compounds are closely related to each other (space group C2/c). In addition, both compounds can be pyrolyzed to yield binary $\mathrm{W}_{6} \mathrm{X}_{12}(\mathrm{X}=\mathrm{Cl}, \mathrm{Br})$ [3]. 
Table 1. Crystal data and structure refinement data of $\left(\mathrm{BiBr}_{2}\right)_{2}\left[\left(\mathrm{~W}_{6} \mathrm{Br}_{8}{ }^{i}\right) \mathrm{Br}_{6}{ }^{a}\right]$.

Empirical formula

Formula weight

Temperature

Wavelength

Crystal system

Space group

Unit cell dimensions

Volume

Z

Density (calculated)

Absorption coefficient

$F(000)$

Crystal size

$\Theta$ range for data collection

Index ranges

Reflections collected

Independent reflections

Completeness, $2 \Theta=24.94^{\circ}$

Refinement method

Data / parameters

Goodness-of-fit on $\mathrm{F}^{2}$

Final $R$ indices $[I>2 \sigma(I)]$

$\mathrm{R}$ indices (all data)

Largest diff. peak and hole
$\mathrm{Bi}_{2} \mathrm{~W}_{6} \mathrm{Br}_{18}$

$2959.44 \mathrm{~g} / \mathrm{mol}$

293(2) K

$71.073 \mathrm{pm}$

monoclinic

$P 2_{1} / C$

$\begin{array}{ll}a=981.8(2) \mathrm{pm} & \alpha=90^{\circ} \\ b=1305.9(2) \mathrm{pm} & \beta=101.81(2)^{\circ} \\ c=1256.8(2) \mathrm{pm} & \gamma=90^{\circ}\end{array}$

$1.5772(5) \mathrm{nm}^{3}$

2

$6.23 \mathrm{~g} / \mathrm{cm}^{3}$

$55.7 \mathrm{~mm}^{-1}$

2480

$0.16 \times 0.16 \times 0.04 \mathrm{~mm}^{3}$

2.12 to $24.94^{\circ}$

$-11 \leq \mathrm{h} \leq 11,-15 \leq \mathrm{k} \leq 15,-14 \leq \mathrm{I} \leq 14$

15341

$2732\left(\mathrm{R}_{\text {int }}=0.073\right)$

$98.8 \%$

Full-matrix least-squares on $\mathrm{F}^{2}$

2732 / 118

0.969

$\mathrm{R} 1=0.032, \mathrm{wR} 2=0.069$

$\mathrm{R} 1=0.043, \mathrm{wR} 2=0.072$

2.743 and $-1.813 e \cdot \AA^{-3}$ 
Table 2. Atomic coordinates $\left(x 10^{4}\right)$ and equivalent isotropic displacement parameters $\left(\mathrm{pm}^{2} \mathrm{x}\right.$ $\left.10^{-1}\right)$ of $\left(\mathrm{BiBr}_{2}\right)_{2}\left[\left(\mathrm{~W}_{6} \mathrm{Br}_{8}{ }^{i}\right) \mathrm{Br}_{6}{ }^{a}\right] . U_{\text {eq }}$ is defined as one third of the trace of the orthogonalized $U_{i j}$ tensor.

\begin{tabular}{lrrrr}
\hline & $x$ & $y$ & $z$ & $U_{\text {eq }}$ \\
\hline $\operatorname{Bi}(1)$ & $72(1)$ & $8578(1)$ & $998(1)$ & $27(1)$ \\
$W(1)$ & $5939(1)$ & $6247(1)$ & $40(1)$ & $22(1)$ \\
$W(2)$ & $3577(1)$ & $5643(1)$ & $505(1)$ & $20(1)$ \\
$W(3)$ & $5908(1)$ & $4728(1)$ & $1422(1)$ & $20(1)$ \\
$\operatorname{Br}(1)$ & $5427(2)$ & $6607(1)$ & $1970(1)$ & $29(1)$ \\
$\operatorname{Br}(2)$ & $8244(1)$ & $5345(1)$ & $956(1)$ & $28(1)$ \\
$\operatorname{Br}(3)$ & $6441(1)$ & $5850(1)$ & $-1888(1)$ & $27(1)$ \\
$\operatorname{Br}(4)$ & $3611(1)$ & $7154(1)$ & $-864(1)$ & $26(1)$ \\
$\operatorname{Br}(5)$ & $7164(2)$ & $8048(1)$ & $29(1)$ & $40(1)$ \\
$\operatorname{Br}(6)$ & $1572(2)$ & $6481(1)$ & $1228(1)$ & $37(1)$ \\
$\operatorname{Br}(7)$ & $7080(2)$ & $4312(1)$ & $3444(1)$ & $35(1)$ \\
$\operatorname{Br}(8)$ & $-786(2)$ & $482(1)$ & $1225(1)$ & $39(1)$ \\
$\operatorname{Br}(9)$ & $-251(2)$ & $8094(1)$ & $2948(1)$ & $41(1)$
\end{tabular}


Table 3. Selected bond lengths (in pm) of $\left(\mathrm{BiBr}_{2}\right)_{2}\left[\left(\mathrm{~W}_{6} \mathrm{Br}_{8}{ }^{\mathrm{i}}\right) \mathrm{Br}_{6}{ }^{\mathrm{a}}\right]$.

\begin{tabular}{lr}
\hline W - W: 261.94(7) - 264.13(7) \\
W(1)-W(2) & $262.66(9)$ \\
$W(1)-W(2)$ & $263.10(8)$ \\
$W(1)-W(3)$ & $264.13(7)$ \\
$W(1)-W(3)$ & $263.11(9)$ \\
$W(2)-W(3)$ & $263.02(9)$ \\
W(2)-W(3) & $261.94(7)$
\end{tabular}

W - Bri : 260.1(2) - 262.8(1)

$\mathrm{W}(1)-\operatorname{Br}(1)$ 261.8(1)

$\mathrm{W}(1)-\operatorname{Br}(2)$ $260.1(2)$

$\mathrm{W}(1)-\operatorname{Br}(3)$ 262.2(1)

$\mathrm{W}(1)-\operatorname{Br}(4)$ 261.8(2)

$\mathrm{W}(2)-\operatorname{Br}(1)$ 262.8(1)

$\mathrm{W}(2)-\operatorname{Br}(2)$ 262.5(1)

$\mathrm{W}(2)-\operatorname{Br}(3)$ 261.4(1)

$\mathrm{W}(2)-\operatorname{Br}(4)$ 262.3(1)

$\mathrm{W}(3)-\operatorname{Br}(1)$ 261.8(1)

$\mathrm{W}(3)-\operatorname{Br}(2)$ 260.8(2)

$\mathrm{W}(3)-\operatorname{Br}(3)$ 260.5(1)

$\mathrm{W}(3)-\operatorname{Br}(4)$ 262.5(1)

$\mathrm{W}-\mathrm{Br}^{\mathrm{a}}:$ 257.4(2) - 264.2(2)

$\mathrm{W}(1)-\operatorname{Br}(5)$

264.2(2)

$\mathrm{W}(2)-\operatorname{Br}(6)$

257.4(2)

$\mathrm{W}(3)-\operatorname{Br}(7)$ 262.2(1)

$\mathrm{Bi}-\mathrm{Br}$

$\operatorname{Bi}(1)-\operatorname{Br}(5)$

294.8(2)

$\operatorname{Bi}(1)-\operatorname{Br}(6)$

309.5(2)

$\operatorname{Bi}(1)-\operatorname{Br}(7)$ 290.3(2)

$\operatorname{Bi}(1)-\operatorname{Br}(8)$ 265.9(2), 325.7(2)

$\operatorname{Bi}(1)-\operatorname{Br}(9)$ 261.3(1) 


\section{References}

[1] R. Siepmann, H.G. Schnering, H. Schäfer, Angew. Chemie 1967, 79, 650.

[2] A. Nägele, J. Glaser, H.-J. Meyer, Z. Anorg. Allg. Chem. 2001, 627, 244.

[3]Y.-Q. Zheng, K. Peters, W. Hönle, Yu. Grin, H.G. von Schnering, Z. Kristallogr. 1998, 212, 453.

[4] Y.-Q. Zheng, H.G. von Schnering, J.-H.Chang, Y. Grin, G. Engelhardt, G. Heckmann, Z. Anorg. Allg. Chem. 2003, 629, 1256.

[5] M. Ströbele, H.-J. Meyer, unpublished results.

[6] J.D. Franolic, J.R. Long. R.H. Holm, J. Am. Chem. Soc. 1995, 117, 8139.

[7] M. Ströbele, H.-J. Meyer, Z. Anorg. Allg. Chem. 2010, 636, 63.

[8] S. Tragl, M. Ströbele, J. Glaser, C. Vicent, R. Llusar, H.-J. Meyer, Inorg. Chem. 2009, 48, 3825; S. Dill, J. Glaser, M. Ströbele, S. Tragl, H.-J. Meyer, Z. Anorg. Allg. Chem. 2004, 630, 987.

[9] S. Ihmaine, C. Perrin, M. Sergent, E.H. El Ghadraoui, Ann. Chim. Sci. Mat. 1998, 23, 187.

[10] S. Ihmaine, C. Perrin, M. Sergent, Eur. J. Solid State Inorg. Chem. 1997, 34, 169.

[11] Y.-Q. Zheng, J. Nuss, H.G. von Schnering, Z. Kristallogr. NCS, 1998, 213, 680.

[12] M. Ströbele, T. Jüstel, H. Bettentrup, H.-J. Meyer, Z. Anorg. Allg. Chem. 2009, 635, 822.

[13] M. Ströbele, H.-J. Meyer, Z. Anorg. Allg. Chem. 2009, 635, 1517.

[14] M. Ströbele, H.-J. Meyer, unpublished results.

[15] Y.-Q. Zheng, Y. Grin, H.G. von Schnering, Z. Kristallogr. 1996, Suppl. 10, 96.

[16] Y.-Q. Zheng, H. Borrmann, Y. Grin, K. Peters, H.G. von Schnering, Z. Anorg. Allg. Chem. 1999, 625, 2115.

[17] Y.-Q. Zheng, K. Peters, H.G. von Schnering, Z. Kristallogr. NCS 1998, 213, 681.

[18] Y.-Q. Zheng, K. Peters, H.G. von Schnering Z. Anorg. Allg. Chem. 1998, 624, 506

[19] S. Ihmaine, C. Perrin, M. Sergent, Croatica Chem. Acta 1995, 68, 877.

[20]Y.-Q. Zheng, Y. Grin, K. Peters, H.G. von Schnering, Z. Anorg. Allg. Chem. 1998, 624, 959.

[21] V. Kolesnichenko, L. Messerle, Inorg. Chem. 1998, 37, 3660.

[22] J. Beck, M. Hengstmann, Z. Anorg. Allg. Chem. 1998, 624, 433.

[23] W. Herrendorf, H. Bärnighausen, HABITUS, Univ. Karlsruhe 1993.

[24] G.M. Sheldrick, Acta Crystallogr. 2008, A64, 112. 